Visit us - www.researchjournal.co.in $\square$ DOI : 10.15740/HAS/IRJAES/8.1/183-185

International Research Journal of Agricultural Economics and Statistics Volume 8 | Issue 1 | March, 2017 | 183-185 — e ISSN-2231-6434

\title{
Research Paper Variance estimation using linear combination of Hodges-Lehmann and Quartiles
}

\section{M.A. BHAT, S. MAQBOOL AND T.A. RAJA}

See end of the paper for authors' affiliations

Correspondence to :

\section{M.A. BHAT}

Division of Agricultural Statistics, Sher-e-Kashmir University of Agricultural Science and TechnologyKashmir, KASHMIR (J\&K) INDIA

Email : mabhat.1500@ gmail.com

\section{Paper History :}

Received : 24.01.2017;

Revised : 17.02.2017;

Accepted : 26.02.2017
Abstract : In this paper, we have proposed a class of modified ratio type variance estimator for estimation of population variance of the study variable, when Hodges-Lehmann and Quartiles of the auxiliary variable are known. The bias and mean square error (MSE) of the proposed estimator are obtained. From the numerical study it is observed that the proposed estimator performs better than the existing estimators in the literature.

KeY Words : Simple random sampling, Bias, Mean square error, Hodges-Lehmann, Quartiles, Auxiliary variable.

How To Cite This PAper : Bhat, M.A., Maqbool, S. and Raja, T.A. (2017). Variance estimation using linear combination of Hodges-Lehmann and Quartiles . Internat. Res. J. Agric. Eco. \& Stat., 8 (1) : 183-185, DOI : 10.15740/HAS/IRJAES/8.1/183-185. 